\title{
TECHNOLOGIC TRANSFER PARTICULARITIES IN THE BEGINNING OF THE THIRD MILLENNIUM. A SARS-COV2 PANDEMIC PERSPECTIVE
}

\author{
Claudiu CICEA \\ Bucharest University of Economic Studies, Bucharest, Romania \\ claudiu.cicea@man.ase.ro \\ Stefan Catalin POPA \\ Bucharest University of Economic Studies, Bucharest, Romania \\ catalin.popa@man.ase.ro \\ Catalina Florentina ALBU \\ Bucharest University of Economic Studies, Bucharest, Romania \\ catalina.albu@man.ase.ro \\ Cezar SIMION \\ Bucharest University of Economic Studies, Bucharest, Romania \\ cezar.simion@man.ase.ro
}

\begin{abstract}
Technology transfer is one of the most important vectors for promoting technical progress in a society and for economic growth in general. It is a very complex process, with major implications on the standard of living of a population and on the level of competitiveness for a national economy. In this paper we propose to analyze the main meanings of the concept of technology transfer, the concrete ways of achieving it, the actors that are involved as well as the ways of evaluation. Particular attention will be paid to the particularities of technology transfer in the current context of the medical (and economic) crisis generated by the SARS-VOC2 virus pandemic.

Keywords: technologic transfer; know-how; SARS-COV2; SME's; economic growth.
\end{abstract}

\section{INTRODUCTION}

In general, technological transfer means a complex process through which scientific and technical discoveries made in specialized entities (usually higher education institutes, research institutes, laboratories) are transferred to specialized entities in the field of production or services. Among other factors that have a great influence over the performance of an economy, such as direct investment 
(Cicea et al., 2009; Vasilescu et al., 2003), general government expenditure and education level of the population (Cicea et al., 2019), it is obvious that technology transfer is a fundamental element for the progress of any society, having an important influence on local or global economic growth and development.

In other words, technology transfer expresses a process of disseminating ideas, discoveries, knowledge, inventions or innovations from the researcher (regardless of the form of its organization) to the general public (Babes Bolyai University Cluj, 2016). According to the same sources, the transfer process can be done in several ways, such as:

- partnership and collaboration relations with the economy (industry, transports, constructions, agriculture etc.);

- scientific publications (specialized journals) or scientific conferences;

- human resource trainings (especially for know-how transfer);

- the process of patenting or licensing inventions and innovations.

Other authors (Cluj-Napoca Technology Transfer Center INOE, 2011) consider that technology transfer represents "the introduction or acquisition in the economic circuit of specific technologies and equipment, equipment and installations resulting from research, in order to obtain new processes, products or services or improved, market-driven or innovative behavior, including the activity of disseminating information, explaining, transferring knowledge, advising and communicating with nonexperts on the results of basic, applied and pre-competitive research". According to the same source, technology transfer can be done with the help of a specific network, consisting of entities focused on innovation, invention and technology transfer processes. This network has a significant influence on the communication process between the beneficiaries of technology transfer (corporations, SMEs etc.) and producers of inventions and innovations (higher education institutes, research institutes, laboratories operating in the field of research).

\section{THE ESSENCE OF TECHNOLOGIC TRANSFER PROCESS}

The technological process involves the collaboration between the scientific environment (represented by researchers, professors, experts in the field) and the business environment (entrepreneurs, businessmen, managers). the former are those who make an invention, innovation, a new technology, while the latter are those who put it into practice, implement it. In essence, the technology transfer process can be broadly described as shown below: 
Cicea, C., Popa, S.C., Albu, C.F., Simion, C.

TECHNOLOGIC TRANSFER PARTICULARITIES IN THE BEGINNING OF THE THIRD MILLENNIUM.

A SARS-COV2 PANDEMIC PERSPECTIVE

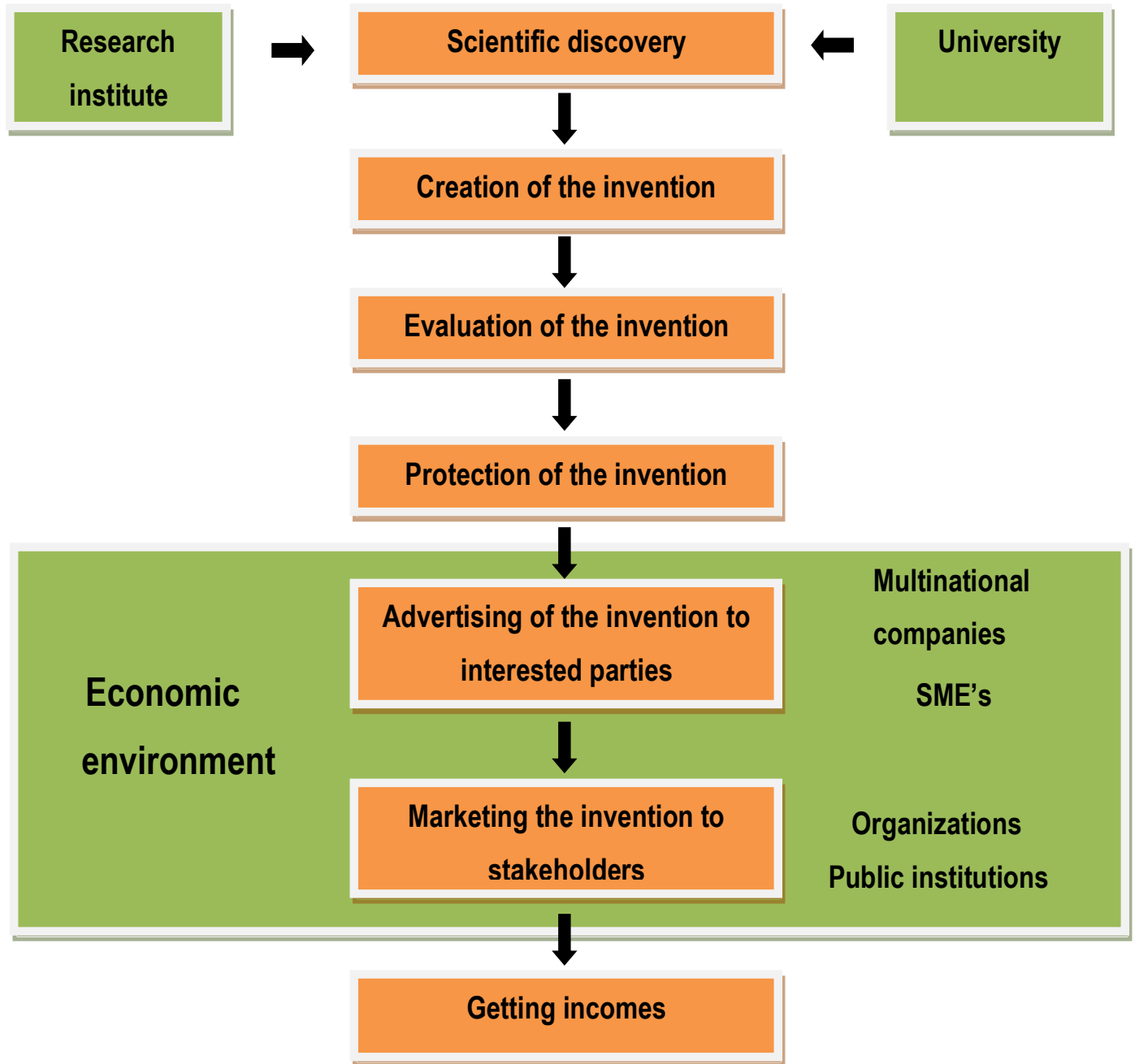

FIGURE 1. GENERAL SCHEME OF TECHNOLOGIC TRANSFER

Source: author conception, based on Tseng \& Raudensky, 2014

Going further with the analysis, we can specify that the technology transfer has several characteristics, as follows:

a) it is the process by which a transfer of know-how (knowledge, skills, abilities, production and managerial methods, etc.) is ensured between governmental bodies (central or local), higher education institutions (universities) or research institutes and organizations. which acts in the sphere of production of goods or provision of services, in order to disseminate it widely to as many users as possible and for its capitalization and marketing in the form of new products and services (Ranea et. al, 2012). b) from a legal point of view, it is manifested on the basis of a specialized document (agreement or contract) signed by two parties - the technology owner and the beneficiary (buyer) of technology (Filipoiu, n.d.). The owner of the technology (or the holder of an invention or know-how) sells the object of the contract to the buyer (who may be a person or a company). 
Cicea, C., Popa, S.C., Albu, C.F., Simion, C.

TECHNOLOGIC TRANSFER PARTICULARITIES IN THE BEGINNING OF THE THIRD MILLENNIUM.

A SARS-COV2 PANDEMIC PERSPECTIVE

c) From a procedural point of view, technology transfer is a sub-process of innovation or as a complementary process (Manolea, 2005). According to the same author, technology transfer can take the form of the transfer between fundamental research and applied research, between applied research and industrial research or the transfer of the results of innovative activities to the applied activity. From the same point of view, technology transfer represents the totality of processes that involve the dissemination of new information in a certain field, the transmission of knowledge and know-how, the acquisition of modern equipment and machinery for the practical application of research results for product development and new services (University of Petroșani, 2015).

Given the importance of technology transfer in the economic development of each nation, it is useful to present how they are actually achieved. Thus, there are 5 main ways of manifestation of technology transfer (Popescu, 2016), presented in the figure below.

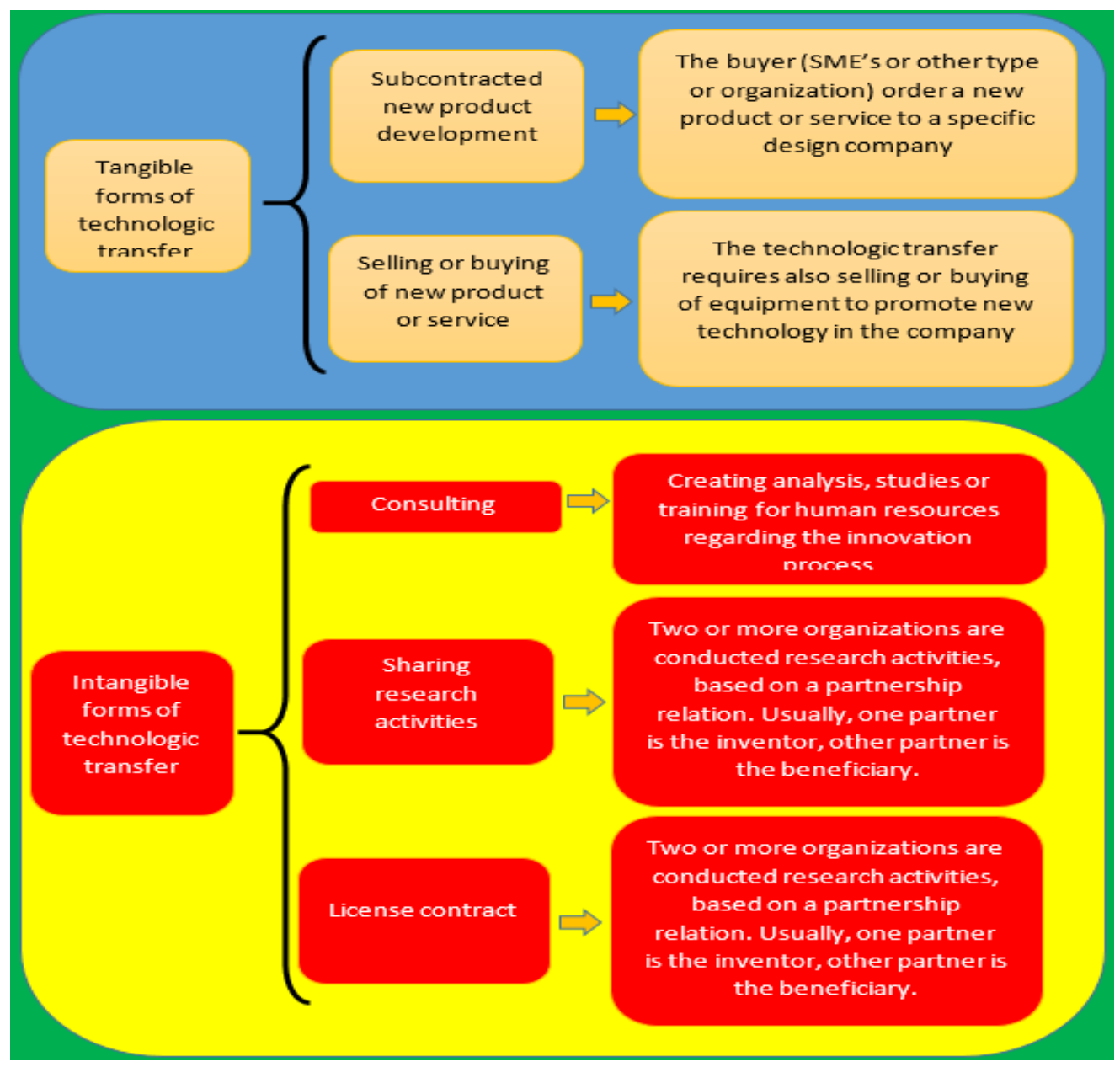

FIGURE 2. FORMS OF TECHNOLOGICAL TRANSFER

Source: Author conception based on Popescu, 2016 
According to the same author (Popescu, 2016), technology transfer takes two forms: a. vertical technology transfer. It involves a dissemination of information, methods, techniques, ideas, know-how from the field of research to the field of real economics. It involves traversing (in part or in full) the circuit from basic (fundamental) research to applied research and industrial application. b. horizontal technology transfer. It involves a dissemination of information, methods, techniques, ideas, know-how in the same sphere (either in the field of research, or most often in the field of the real economy).

Organizations acting in the field of technology transfer contribute to the realization of a network of ideas, information and know-how in such a way as to ensure access to knowledge for the general public (Regional Cross-Border Innovation Strategy, n.d.).

Experts in the field (Ranea et. Al., 2012) consider the following types of organizations acting in the field of technology transfer:

1. Industry Liaison Office - represents an interface or bridge between the field of research (and the actors operating here - universities, research institutes, laboratories, etc.) and the field of real economy (organizations, SMEs that are beneficiaries of technology transfer).

2. Technology transfer center - a separate entity in the technology transfer process that deals with stimulating the implementation in practice of the results of scientific research, acting as a catalyst for the process. It is usually found in higher education institutes, business incubators, government institutions, etc.

3. Innovation center - are components of the technology transfer process that deals with accelerating the process of developing new products or services. From this point of view, the innovation centers are more inclined towards the practical, applicative part of the technology transfer process. 4. Technological resource center - provides assistance in the field of technology transfer; 5. Business incubator - provides the necessary conditions for technology transfer based on the establishment and development of new enterprises (especially SMEs), focused on high technology. 6. Science park - is an entity that acts in the field of technology transfer, being usually within a higher education institution. Within these science parks, a joint venture strategy is usually applied between two broad categories of actors - researchers or scientists and government bodies (central or local). 7. Technology broker - as in the case of the industry liaison office, the technology broker is an intermediary (an interface) that ensures contact between suppliers and beneficiaries of technology. 


\section{EVALUATION OF THE TECHNOLOGIC TRANSFER}

Over time, the evaluation of technology transfer has been one of the main problem faced by this process, from the perspective of determining whether it was a success (recorded the expected results) or a failure (the effects obtained were not in line with predetermined objectives).

From this point of view, the evaluation of technology transfer is important because it has positive effects on several levels (O'Keefe, 1982):

- better motivation of all actors involved in this process; indeed, evaluation contributes to a greater interest on the part of the actors involved in carrying out the technology transfer;

- a better knowledge and understanding of the efficiency of technology transfer as well as its strengths and weaknesses;

- an improvement of the decision-making system regarding the technology transfer process;

- a better substantiation of the whole process at the same time with an optimal justification of the budget.

In general, technology transfer evaluation is a complex process, similar to the technology transfer process itself. It can be performed by an entity endogenous (internal) to the technology transfer process or by an exogenous (external) one. In the first case, the major advantage is that the entity is familiar with the process itself and the implementation costs are low. In the second case, the advantage is represented by the high degree of objectivity of the evaluation.

Another particularly important issue in the process of evaluating technology transfer is the establishment of the objectives of the evaluation program, on which the type of information required depends. Thus, there are 3 types of data (O'Keefe, 1982):

- information of minor importance. It refers to the information that characterizes the entire program, regarding the activities involved, the number of participants and the resources involved. This type of information is easy to collect, does not involve significant financial resources, but also has a limited level of use;

- information of medium importance. This type of information takes into account those data that refer to the reaction of the participants in the program;

- information of high importance. It is the information that takes into account the results of the program, having a direct connection with the adoption of new ideas, know-how, with the learning process of the participants etc.

Last but not least, in the process of evaluating the transfer of technology, it is necessary to specify very clearly which are the performance criteria that underlie the evaluation process (O'Keefe, 1982). Regardless of their nature, the criteria must take into account at least two principles: the measurability 
Cicea, C., Popa, S.C., Albu, C.F., Simion, C.

TECHNOLOGIC TRANSFER PARTICULARITIES IN THE BEGINNING OF THE THIRD MILLENNIUM.

A SARS-COV2 PANDEMIC PERSPECTIVE

of the proposed objectives (absolutely all proposed objectives must be, to one degree or another, quantifiable) and the finiteness of the time period for which the evaluation is made (time during which the evaluation is made must be well defined).

\section{TECHNOLOGICAL TRANSFER IN THE CONTEXT OF SARS-COV2 PANDEMIC}

Undoubtedly, the year 2020 will go down in history through the pandemic generated by the SARSCOV2 virus, one of the most contagious viruses that have circulated on the planet's surface. One hundred years after the 1918 pandemic (Spanish flu), humanity has faced an unprecedented medical crisis that has affected the entire society, in all areas (economic, social, medical, political, legal etc.). The concern for the study of this pandemic and the amplitude of its effects is also revealed by the large number of papers that have been written recently on this topic (only in January 2020 - June 2020, were indexed over 20,000 papers in the Web of Science database which treats, in one form or another, the problem of the pandemic).

It was obvious that the field of technology transfer could not escape this global phenomenon. If we try to make a careful analysis of the influence of the SARS-COV2 pandemic on the technology transfer process (and, in general, of the way this process was carried out in pandemic conditions), we can appreciate that the period elapsed from the start of the pandemic to present (January - June 2020) has accentuated the process of technological transfer, especially in the medical field. The engine of this technological transfer was the institutes of higher education and research institutes (especially those in the medical field), which acted on several levels to respond as quickly as possible to the priorities of this period.

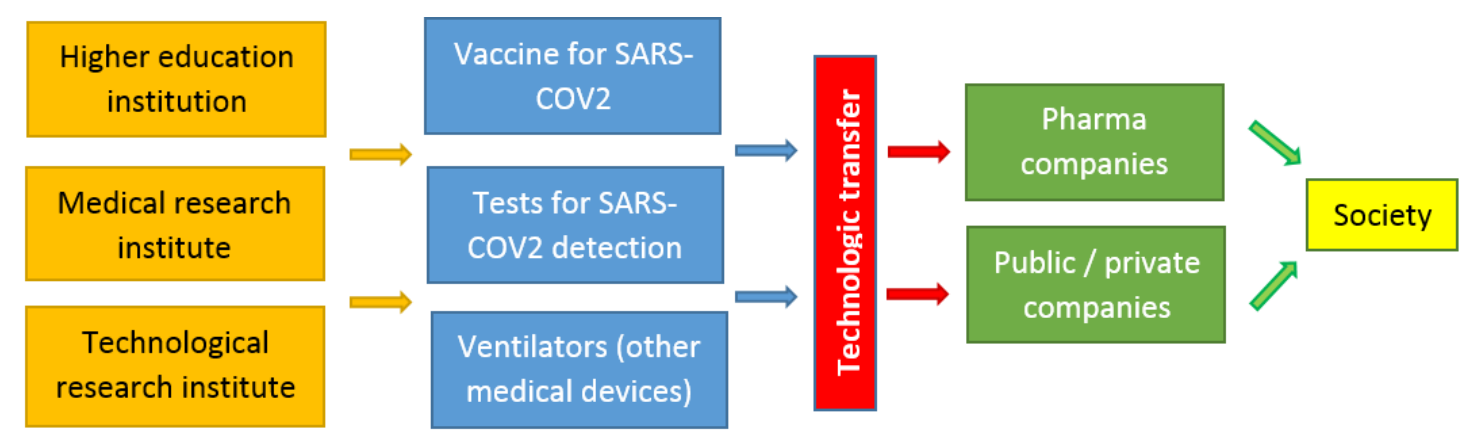

FIGURE 3. MAIN CHARACTERISTICS FOR TECHNOLOGIC TRANSFER IN SARS-COV2 PANDEMIC CRISIS

Source: Author's own conception

Indeed, many higher education institutions have focused on finding a quick solution to this unprecedented crisis. In this context, we can mention Oxford University which carried out a very active 
campaign in the first half of 2020, to identify a possible vaccine against this virus (Oxford University, 2020). Also, the same university has stood out in the field of medical ventilators (OxVent) which are less performant, but easier to produce as well as the field of rapid tests for COVID-19 (Technology Transfer Innovation, 2020).

Moreover, the coronavirus crisis has brought scientists closer to the economic and social environment. In other words, the rapidity with which the virus spread and blocked the entire planet (over $75 \%$ of the world's population was forced into quarantine, for different periods of time) generated the acute need for a rapid and adequate response. As a result, researchers and businesspeople approached each other and worked together to find appropriate solutions to the existing situation.

Moreover, some research institutions or universities have prioritized research activity and paid special attention to those actions capable of generating effects in the fight against SARS-VOC2, to the detriment of other common research activities. An example of this is the University of Michigan, which focused its research on inventing high-performance ventilators and identifying a vaccine, based on a collaboration between scientists (members of academic environment) and the business community (Tech Transfer Central, 2020).

From another perspective, the coronavirus crisis (SARS-COV2) has had beneficial effects on technology transfer not only in the medical field, but also in the field of information technology. Forced by circumstances, many activities that previously involved the presence of the individual in person have moved to the online environment (business meetings, educational process in schools, banking services, purchases of consumer goods, etc.). As a result, the field of information technology (especially that of video conferencing or online platforms) has exploded following the COVID-19 crisis.

\section{CONCLUSIONS}

Undoubtedly, at the beginning of this millennium, the issue of technology transfer is a very topical one. At present, in the context of accentuated globalization, one cannot speak of an economic growth of any nation or of the well-being of a population of a country without omitting the issue of technology transfer. As we described in the previous sections, the technology transfer process is a complex one, involving many participating entities; also, its evaluation based on well-established criteria is vital for the development of an efficient process, with beneficial results in the real economy. In the context of the coronavirus crisis (SARS-COV2), we appreciate that the process of technology transfer has intensified (especially in the medical field). Thus, important steps have been taken forward in terms of identifying effective treatments against the virus (drugs, vaccines, etc.), as well as in terms of medical equipment (medical ventilators, virus identification tests, protective equipment, etc.). From this 
point of view, we can appreciate that the SARS-COV2 crisis had beneficial effects on the technology transfer process, having a catalytic role for the whole process.

\section{REFERENCES}

Centrul de Transfer Tehnologic Cluj-Napoca INOE (2011). Inovarea si transferul tehnologic, retreived at https://centi.ro/inovarea-si-transferul-tehnologic-instrumente-de-aliniere-a-imm-urilor-lacerintele-economiei-de-piata

Babes Bolyai University of Cluj, (2016). Oficiul de Management şi Transfer Tehnologic şi Cognitiv (OMTTC) Regulament de organizare și funcționare. https://cercetare.ubbcluj.ro/wpcontent/uploads/2016/11/hs-ubb-oficiul-de-management-tehnologic.pdf

Cicea C., Popa I., Marinescu C., Stefan S. (2019). Determinants of SME's performance: evidence from European countries, Economic Research-Ekonomska Istraživanja. 32(1): 1602-1620

Cicea C., Vailescu I., Banacu C. (2009). Direct investment analysis, starting point to attract new investors in economy. A macrosystemic approach, Proceedings of the 11th IBIMA Conference, Cairo, Egypt

Filipoiu, D. I. (n.d.). Inovarea și transferul tehnologic (chapter 5), http://andrei.clubcisco.ro/cursuri/5master/mti-misc/CAP5_LPMITT_Inov.TT.pdf

Manolea, G. (2005). Transferul tehnologic - soluţie de valorificare a rezultatelor cercetărilor ştiinţifice, Buletinul AGIR nr. 3. http://www.agir.ro/buletine/172.pdf

Năstase, G.I., Badea, D.C., Năstase, D.I. (n.d.) Modele ale dezvoltării inovatoare prin ştiinţă. http://cogito.ucdc.ro/nr 3/12\%20\%20MODELE\%20ALE\%20DEZVOLTARII\%20INOVATOARE\%20PRIN\%20STIINTA\%20_rom .pdf

O'Keefe, T. (1982). Evaluation Technology Transfer: Some problems and solutions, The Journal of Technology Transfer. 6(2): 53-57

Oxford University (2020). Oxford COVID-19 vaccine to begin phase II/III human trials, retrieved at http://www.ox.ac.uk/news/2020-05-22-oxford-covid-19-vaccine-begin-phase-iiiii-human-trials

Popescu, M. (2016). Managementul inovării. Editura Universității Transilvania din Brașov

Ranea, C., Filipoiu, I.D., Hadar, A., Marin, A., Badea, D. (2012). Bazele managementului inovării și transferului tehnologic. https://imnr.ro/public/documents/curs-bazele-mangementului-itt.pdf

Strategia Regionala Transfrontaliera pentru Inovare (n.d.). Metode pentru inovare si transfer tehnologic in industrie, retrieved at http://www.arott.ro/files/2-3.18/Metode\%20pentru\%20inovare\%20si\%20transfer.pdf

Tech Transfer Central, (2020). Coronavirus brings challenges and changes to TTO operations, retrieved at https://techtransfercentral.com/2020/04/29/coronavirus-brings-challenges-and-changes-totto-operations/

Technology Transfer Innovation (2020). University Technology Transfer and the Coronavirus Crisis, retrieved at http://www.technologytransferinnovation.com/tt-and-coronavirus.html

Tseng, A., Raudensky, M. (2014). Performance Evaluations of Technology Transfer Offices of Major US Research Universities, Journal of Technology Management \& Innovation, 9 (1): 93-102

Vasilescu, I., Cicea, C., Dobrea, C. (2003). Eficienta investitiilor aplicata, Lumina Lex Publishing House, Bucharest

University of Petroșani (2015). Codul de etică în cercetarea ştiinţifică, https://www.upet.ro/cercetare/doc/ETICA\%20IN\%20CERCETARE.pdf 